\title{
Variability of some Lutetian building stones from the Paris Basin, from characterisation to conservation
}

Gilles Fronteau*, Claire Moreau, Céline Thomachot-Schneider, Vincent Barbin

GEGENAA, Université de Reims Champagne-Ardenne, Centre de Recherche en Environnement et Agronomie, 2 Esplanade R. Garros, F-51100 Reims, France. gilles.fronteau@univ-reims.fr

\begin{abstract}
Lutetian limestones of the Paris Basin were used from antiquity to today as building materials (e.g. Paris and Rheims Notre-Dame cathedrals), but quarries gradually closed down and started to disappear from the landscape and hence from memory. These limestones show important vertical and lateral variations and shift of facies, and, within the same area, the building stones can have very different petrographical and petrophysical properties. The use of sometimes very different stones may cause problems for the conservation of cultural heritage monuments because of their great response variability to treatments. In our study area, the building stone's sedimentological and petrophysical properties were characterized, as well as their behaviour in construction, in particular with respect to their durability or state of conservation. The cartography of these various microfacies, from abandoned quarries and old buildings, would allow a better management o fmineral resource sin this region.
\end{abstract}

Keywords: Limestones, Stone provenance, Monument, Porosity, Weathering, Durability.

\section{Introduction}

Lutetian limestones are major building stones from the centre of the Paris Basin. Their use is attested from antiquity (Bedon, 1984) to nowadays when more than ten quarries remain in activity. These limestones are even an integral part of the collective imagination through the large Gothic cathedrals (Paris, Rheims) or the catacombs: old underground quarries, which were used to store bones from the Parisian cemeteries from 1780 (Gély et al., 2000 ). The term Lutetian itself refers to the Paris name during antiquity

Lutetia and thus to the stone of Paris. Even if discussions exist to redefine the Ypresian/Lutetian boundary stratotype (Molina et al., 2000), the current stratotype for this stage is localized in Oise (Schubnel et al., 2000), one of the largest building stones deposit of the centre of the Paris Basin (Noël, 1970; Blanc et al., 2002). In the Lutetian sedimentary sequence, some terms derive directly from quarrymen's vocabulary (Viré, 1997), which reinforces the close links between this geological stage and its buildingstones. For example, the "banc à vérins" (French term for screws) corresponds to banks containing internal moulds of Campanilopa (Cerithium) giganteum, which appear in the quarries like large screws inserted in the stone (Benoit et al., 2000).

The marine Lutetian limestones of the Paris Basin cover a large surface area and many regions: Valois, Vexin, Tardenois, Parisis, and Soissonnais. In all these regions, limestones were extracted, either from open air or from underground quarries. Depending on the circumstances, this exploitation succeeded in being maintained until today (Oise, Soissonnais) or else gradually disappeared during the last centuries (Laonnois, Fismois).

Our study area corresponds to the Eastern part of the limestone layer and more precisely to the regions around Soissons, Laon and Rheims (Fig. 1). There, the building stone quarries are numerous, even if nowadays their numbe rbecomes more and more restricted. In the Marne area for example, the last building stone quarry which was at Courville and provided the stone for the restoration of Rheims cathedral, closed in 2005. Outcrops tend to disappear and numerous quarry faces, excavation marks, and even quarries or sites accesses were erased from maps, landscape and memory. Lutetian limestone quarries are no longer part of the industrial or cultural resources but have become "natural" hazards and risks, because they may collapse (Devos et al., 2005; Kaufmann and Quinif, 1999), or "natural" heritage e.g. for the preservation of bats. This causes problems for building conservation and in 
order to provide restoration projects with appropriate stones, availability and durability of local building stones must be characterized (Zezza, 1990). Therefore, limestone facies must be analysed in situ and on monuments (Dreesen and Dusar, 2004) and lithological maps (Martinez-Torrez, 2007) must be joined to petrographical and petrophysical analyses of materials.

\section{Materials and methods}

The different Lutetian limestones studied were analysed using classical petrographical methods including, facies characterization using Folk and Dunham classifications (Folk, 1959, 1962; Dunham, 1962) and paleontological analyses. Microfacies characterization was carried using polarizing microscopy (Olympus BX60 with Tri-CCD Camera Sony DXP 930 and image analysis software from Microvision Instruments).

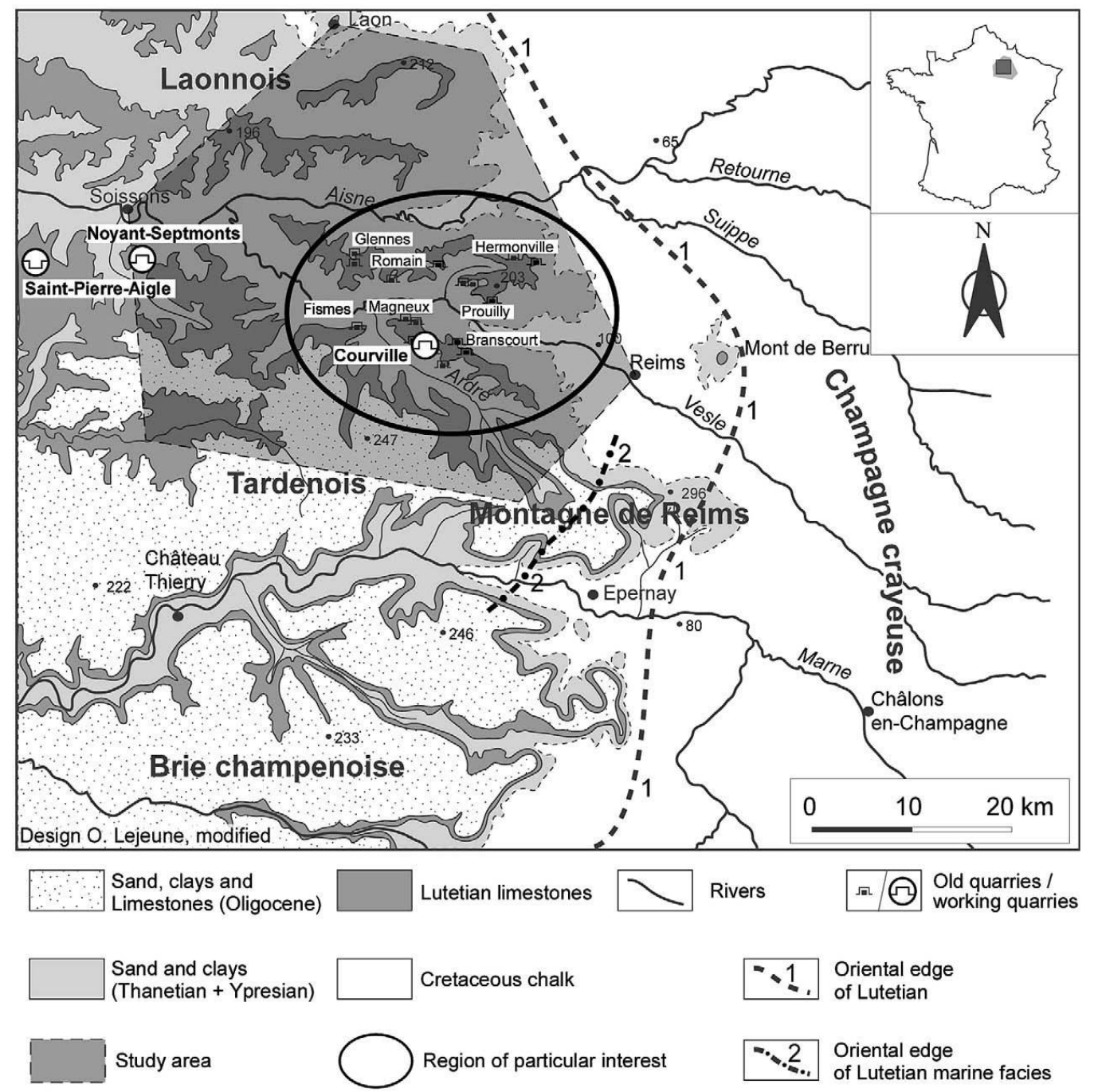

Fig. 1. Our study area: the oriental edge of Lutetian limestones deposits

Petrophysical characterizations were carried using normalized tests recommended on building stones: total and water open porosity: EN 1936 (ECS, 2007), sound speed propagation: EN 14579 (ECS, 2005), capillary water absorption: EN 1925 (ECS, 1999). In addition, the determination of water uptake coefficient by capillary, W [kg $\left.\mathrm{m}^{-2} \mathrm{~h}^{1 / 2}\right]$, which represents the amount of water absorbed per square meter as a function of square root of time, was very useful for assessing the success of water-repellent treatment. 


\section{Variability in the sedimentary sequence}

The Lutetian sedimentary sequence in the Paris Basin shows important vertical, lateral or geographical variations (Blondeau, 1965; Gély, 1996). Indeed, during this geological time (Lutetian Stage), paleogeography was very extremely variable and the shorelines as well as the sedimentary environments showed great fluctuations. For example, the transgressive system tract shows an important diachrony in the basin. The lower Lutetian in the stratotype area disappears towards the east and in particular in the study area where the first facies are dated from the middle Lutetian. Moreover, the thickness of the sedimentary sequence decreases largely in the west and marine facies cease to exist in the surroundings of Epernay, where limestones change to shelly sands, unsuitable for construction, before disappearing. During the middle Lutetian, series include various marine facies. Towards the passage to the upper Lutetian, they undergo a continental influence and finally develop into lacustrine facies with some marine gastropod beds (Cerithium limestones) or with the insertion of evaporites. This progradation of the continental facies, accompanied by tectonic movements, which shape the paleogeography of the Paris Basin and cause its separation from the London-Belgium basin, largely influences the geometry and the nature of the last sedimentary sequence deposits (Gély, 1996).

For these sedimentological reasons, Lutetian limestones are organized in a very complex way. Building stones from different quarries or from different beds in the same quarry can have various thicknesses, petrographical natures and petrophysical properties. In the same area, even in the same village, it is possible to find quarrying sites that exploit or have exploited different banks, having different properties, use or aesthetic characteristics. For example, in the surroundings of Soissons, in the present day, only two extraction sites remain: in Noyant-Septmont and in SaintPierre-Aigle (Fig. 1). But whereas the first site exploits the homogeneous and relatively porous facies of the middle Lutetian, the other one is in the upper Lutetian and exploits Cerithium limestones; these stones have a smaller thickness and are less porous (Noël, 1970; Fronteau et al., 1999a). In a same way, Branscourt village in the Marne area seems to be known for having quarries of russet stones and of grey ones (Dolfini, 1920).

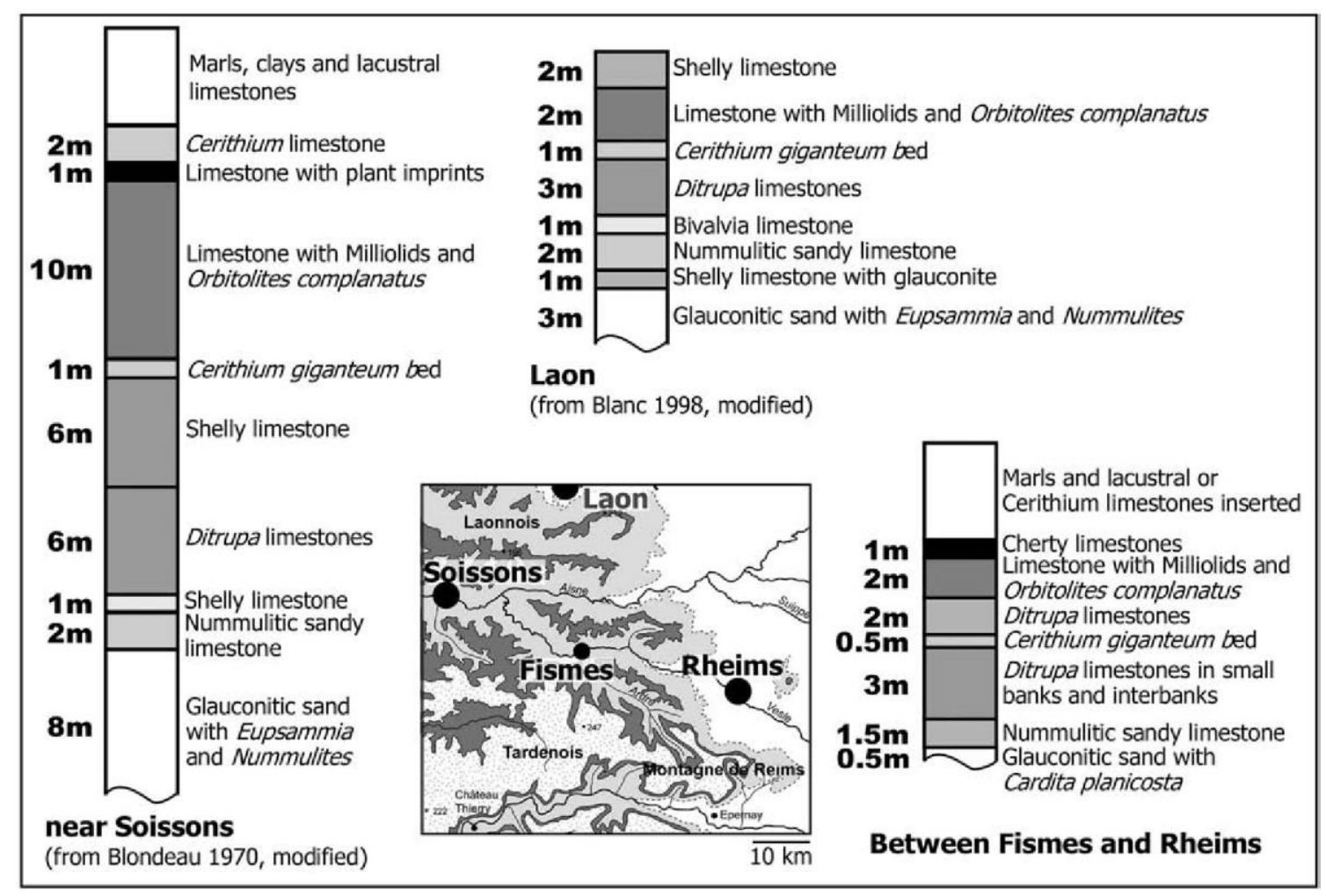

Fig. 2. Variability of the Lutetian sedimentary stack from west to east 

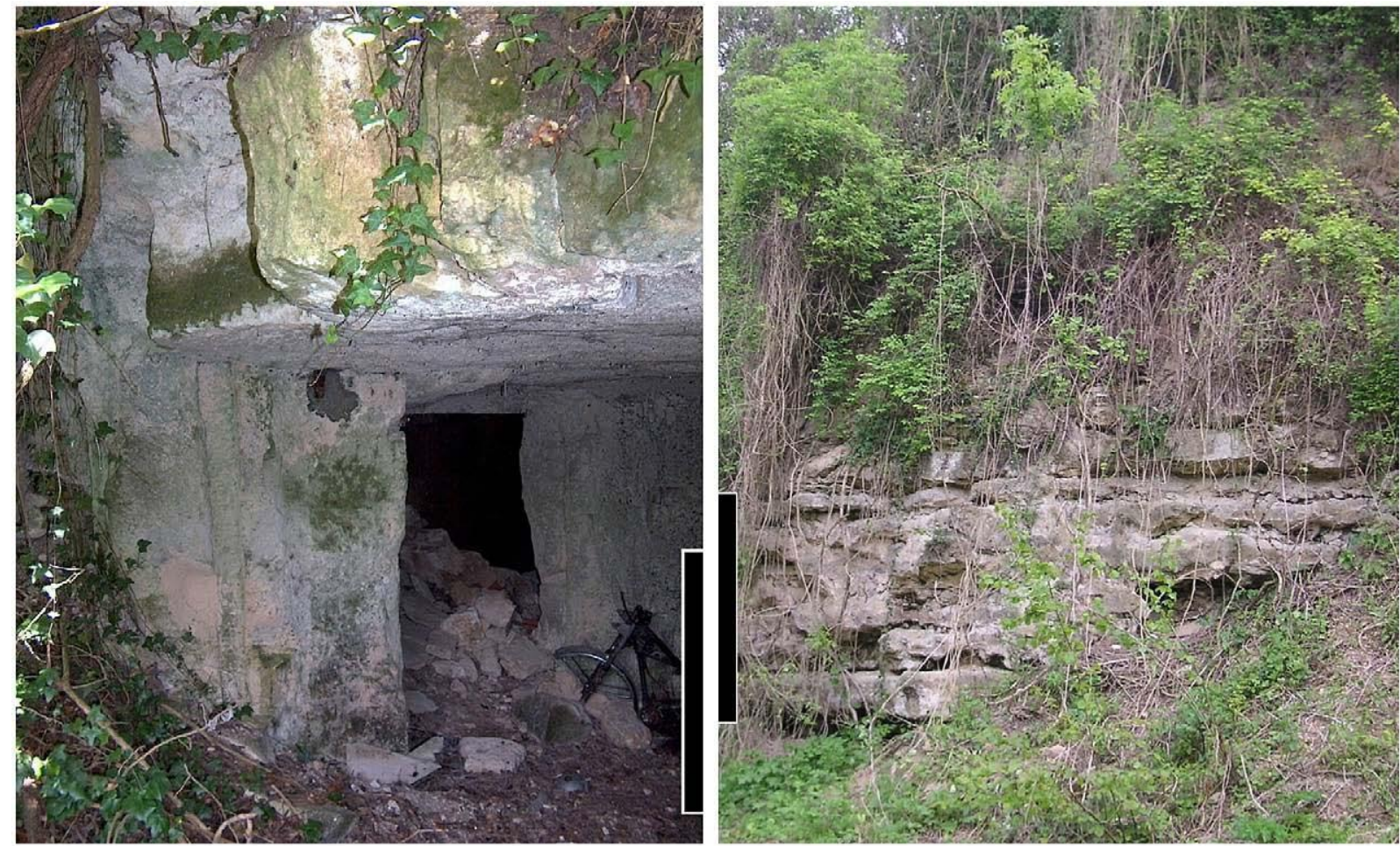

Fig. 3. One of the lateral shift of facies in the Lutetian limestones, the example of the Ditrupa limestones near Fismes. Scale bar about $1 \mathrm{~m}$. Left-hand: in Glennes area, thick homogeneous bank with underground quarry. Righthand: in Branscourt area, small banks with interbanks = unsuitable for underground quarry.

In the area under consideration, the vertical variability of Lutetian limestones is extremely accentuated, with some geographical variations, corresponding to various lateral shifts of facies. This variability depends on sedimentation context and diagenesis evolution. The thickness of the

totalLutetianlayerinthecentreoftheParisBasinisofalmost40 m. But,as shown on Fig. 2, it decreases progressively when moving eastwards: the series being slightly reduced near Soissons and largely reduced in the Laon surroundings and towards Rheims, being less than $20 \mathrm{~m}$ thick near Fismes (Blanc, 1998; Fronteau, 2000). Then, marine limestones disappear and, in the eastern part of the "Montagne de Reims", there is no sediment attributed to the Lutetian at all.

This thickness variation of the sedimentary sequence is accompanied by other phenomena, which increase the complexity of the situation and the variability of the building stones used on a local scale. Indeed, not only the thickness of the layer usable for construction decreases, but, as shown in Fig. 3, facies variation changes from homogenous Ditrupa limestone banks succession to small hard beds alternation, only 20 or $30 \mathrm{~cm}$ thick, with interbanks, easily cracked by frost, of the same thickness. Due to this lateral shift of facies, in the eastern part of the deposit, Ditrupa limestones cannot be quarried using underground methods.

Over a distance of fifty kilometres, the nature and thickness of limestone banks quarried as building stones vary. In the Soissonnais or Laon areas, underground quarries are mainly located in the Ditrupa limestones or in the Campanile giganteum beds (Schubnel et al., 2000), but in the Ardre and Vesle valleys, they are only located in Milliolids and Orbitolites complanatus limestones that are positioned above Ditrupa limestones. 
The lateral shift of the Ditrupa limestone facies or of the russet-red Milliolids limestones formerly quarried in Courville - the two major building stones of the regional middle Lutetian (Fig. 4, Table 1) - can be mapped. But this only in an imperfect way since the large Ailette and Aisne valleys intersect the area and numerous outcrops disappeared after the First World War. Therefore, we studied ancient buildings and monuments preserved in local towns and villages or old quarries.

Analyses of old buildings in villages confirmed the approximate position of the lateral shift of building stone facies. The change of aspect with the disappearance of the grey and porous Ditrupa limestones represented in Fig. 4A, and the appearance of the fine russet stone colour represented in Fig. 4B is characteristic of the surroundings of Fismes. Fig. 5 sums up our investigations in this area. In Longueval, Merval, Perles or Ville-Savoye, the fine cream coloured facies, corresponding to the equivalent of the Courville stone, cannot be observed, and the porous grey Ditrupa limestones are dominant. On the opposite side, old houses in Ventelay, Roucy, Romain and Unchair display door and window frames with materials resembling the stones found on the cathedral of Rheims due to their cream or russet colours and smooth grains. Two distinct areas of Lutetian building stones appear clearly, without connection with the administrative division or the rivers position.

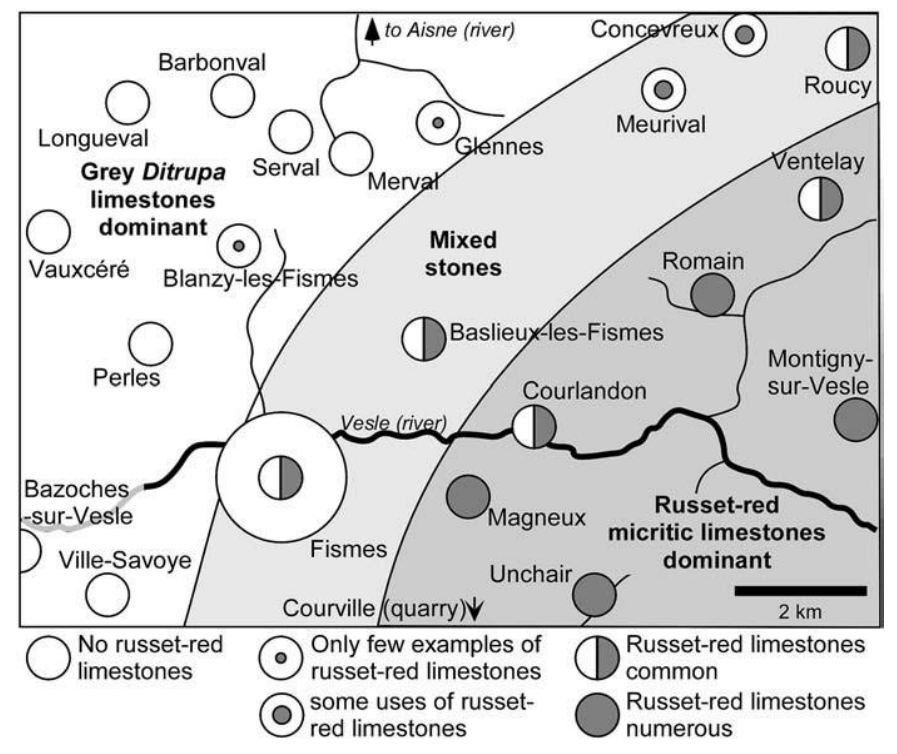

Fig. 5. Lithological map showing the presence or absence of the russet-red limestone facies. In this area, lateral shift of facies is closely related to aesthetic appearance of the cultural heritage.

\section{Variability between Lutetian building stones}

Vertical differentiation of banks by specific names is still a topical practice in many quarries, where each layer has a specific name, generally related to its physical properties. Unfortunately building stones are often quoted only by their locality names and not by their exact name, which would give an indication of quality or bed origin (Roels et al., 2000; Blows et al., 2003; Benavente et al., 2004). In the case of the Lutetian limestones, the differentiation between the banks of a quarry or a region is of great importance.

Table 1

Differentiation between the two main lithologies of Lutetian building stones present in the study area.

\begin{tabular}{lllll}
\hline Building stone type & Limestone classification (Folk) & $\begin{array}{l}\text { Limestone classification } \\
\text { (Dunham) }\end{array}$ & Main fossil markers & Average porosity \\
\hline $\begin{array}{llll}\text { Grey porous limestone } \\
\text { Russet micritic limestone }\end{array}$ & $\begin{array}{l}\text { Biomicrosparite } \\
\text { Biomicrite }\end{array}$ & $\begin{array}{l}\text { Packstone/Grainstone } \\
\text { Wackestone }\end{array}$ & $\begin{array}{l}\text { Ditrupa (serpulid tubes) and miliolids } \\
\text { Orbitolites (foraminifera) and miliolids }\end{array}$ & $35 \%$ \\
\hline
\end{tabular}


FRONTEAU G., Moreau, C., Thomachot-Schneider, C., and Barbin, V., 2010, Variability of some Lutetian building stones from the Paris Basin, from characterisation to conservation: Engineering Geology, vol. 115. p. 158-166. doi:10.1016/j.enggeo.2009.08.001

For example, as shown in Fig. 6, in the Courville quarry, the designed "Banc de Roche" or "rock bank" was sound to be the hardest and the " $1 / 2$ Roche" or "Liais" was the second hardest. Petrophysical characteristics between these two banks and the other beds of the quarry were sound to be very different (12 to $50 \%$ total porosity).

Table 2

Petrophysical variability of Lutetian building stones from Paris Basin.

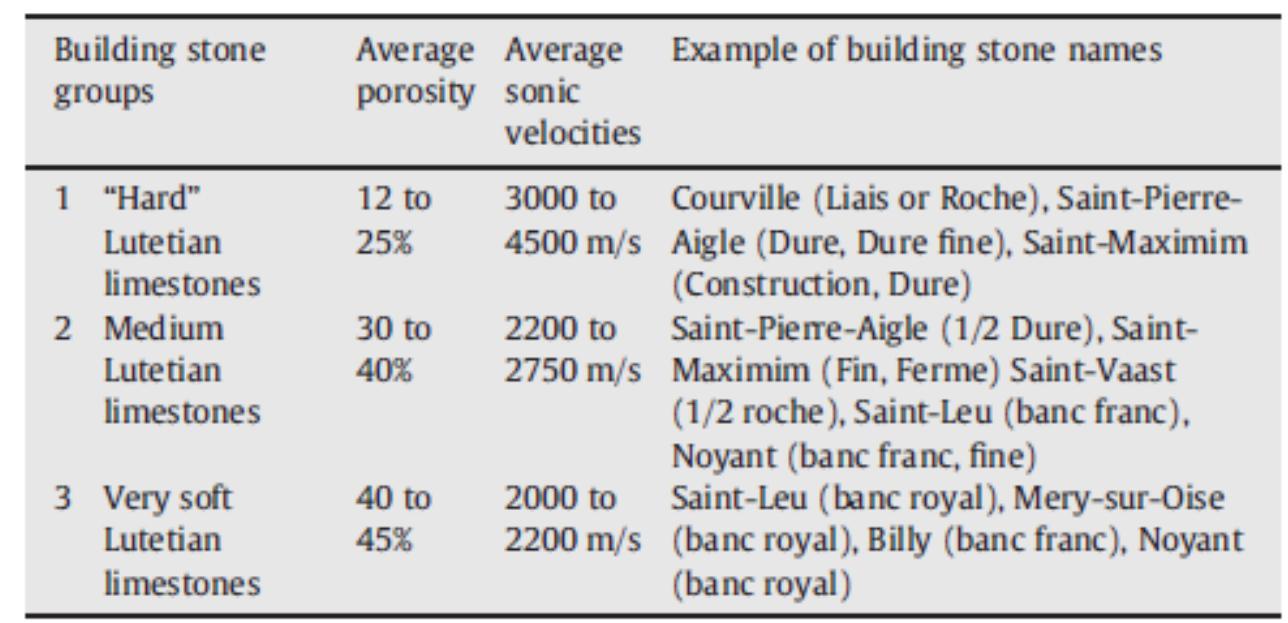

Moreover, considering a large number of Lutetian building stones (Fig. 7), three major groups can be distinguished in these limestones: 1) stones with medium porosity (from 12 to $25 \%$ ) and ultrasonic velocities up to $3000 \mathrm{~m} / \mathrm{s}$, sometimes called "Dure" or hard stones (which include Courville or Saint-Pierre-Aigle building stones), 2) stones with high porosity (from 32 to $40 \%$ ) and ultrasonic velocities around $2500 \mathrm{~m} / \mathrm{s}$, essentially the formerly called "Banc franc" (which include Noyant building stones), and 3) stones with very high porosity (about 40 to $45 \%$ ) and ultrasonic velocities around $2000 \mathrm{~m} / \mathrm{s}$ with some banks known as "Banc royal". Thus, building stones from these different groups (Table 2) can have a porosity varying from 15 to 45\% (Blondeau, 1970; Fronteau, 2000), and therefore very variable use and durability (Andriani and Walsh, 2003; Topal and Sözmen, 2003; Beck et al., 2003).

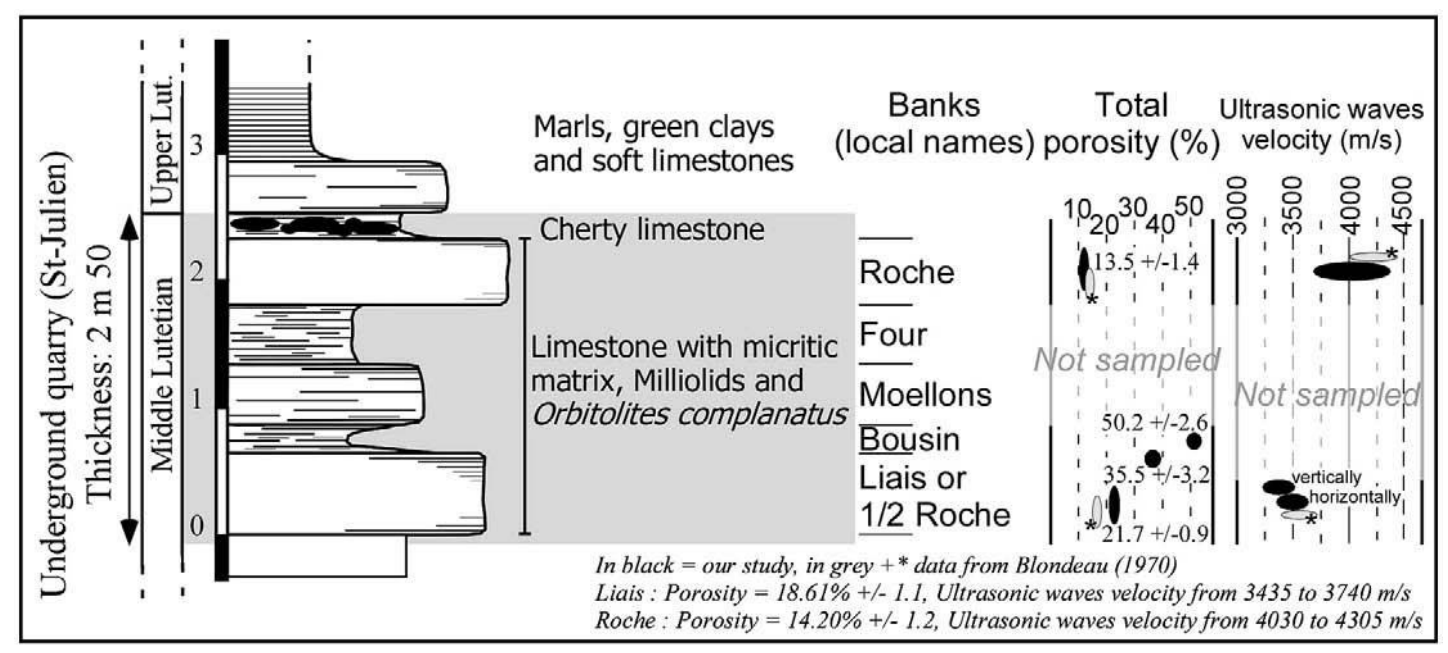

Fig. 6. Variability between the banks in the Courville building stone quarry. 
FRONTEAU G., Moreau, C., Thomachot-Schneider, C., and Barbin, V., 2010, Variability of some Lutetian building stones from the Paris Basin, from characterisation to conservation: Engineering Geology, vol. 115. p. 158-166.

doi:10.1016/j.enggeo.2009.08.001

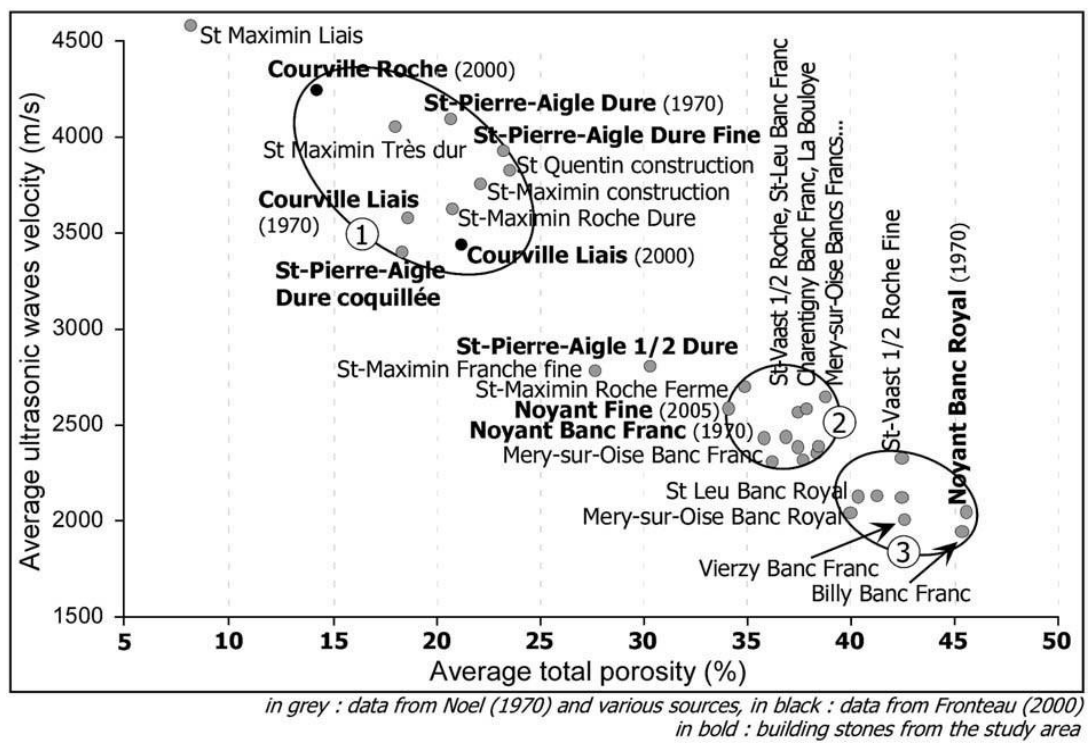

Fig. 7. Correlation between the percentage total porosity and ultrasonic wave velocity of various building stones coming from the Lutetian limestones of the Paris Basin. 1: medium porosity stones, 2: high porosity stones, 3: very high porosity stones.

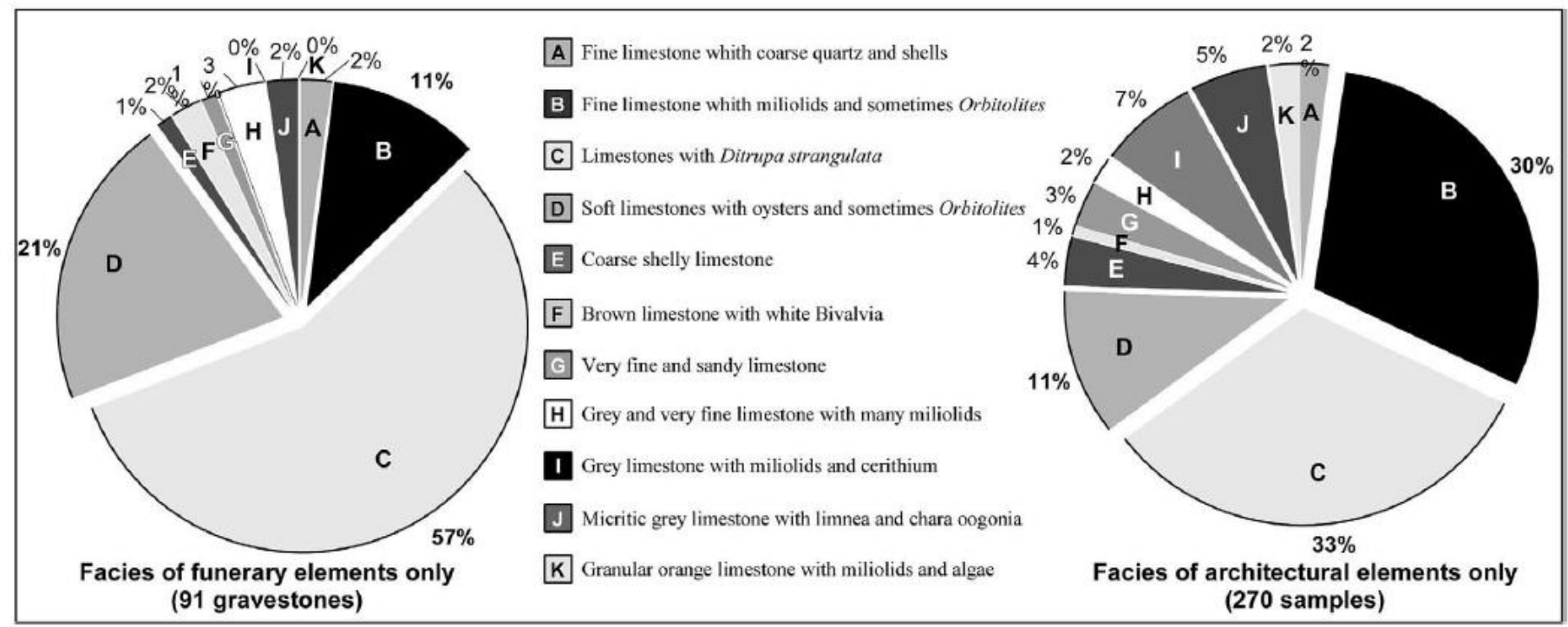

Fig. \& Petrographical distribution of Gallo-Roman block from the archaeological site of Belin (Rheims).Left-hand: in gravestones only, Right-hand: in architectural elements only.

\section{Importance of Lutetian limestones variability in cultural heritage}

This sedimentological and petrophysical characterisation of Lutetian limestones facies variability is very important in the field of cultural heritage conservation because these stones are used in many monuments, such as the cathedral "Notre-Dame" or the Saint-Remi basilica in Rheims, two monuments listed within UNESCO's World Heritage List. The Aisne area is one of the first localities in France for the number of protected monuments (e.g. the cathedral of Laon or the Saint-Jean-des-Vignes abbey in Soissons).

Rheims, which was the capital of a Roman province, the Belgian Gaul (Gallia Belgica), under the name of Durocortorum, has an important number of archaeological sites where original building stones are sometimes 
FRONTEAU G., Moreau, C., Thomachot-Schneider, C., and Barbin, V., 2010, Variability of some Lutetian building stones from the Paris Basin, from characterisation to conservation: Engineering Geology, vol. 115. p. 158-166.

doi:10.1016/j.enggeo.2009.08.001

preserved. The discovery in 1999, of a very considerable quantity of limestone blocks allows us to establish the exceptional depth of Roman knowledge of the variability of these materials.

Out of the 451 studied blocks, archaeological analyses characterized 91 as parts of funerary steles and 270 as architectural elements, including bases, walls, pediments and columns. Petrographical investigation shows the use of 16 different facies, with at least $90 \%$ of the elements coming from the various layers of the Lutetian limestones. Funerary steles are mainly soft and very porous facies, although a rather hard lacustral limestone with Limnea is sometimes used. Eighty nine percent of the steles are made of the three major groups of stones corresponding to the main beds of the middle Lutetian (cf. supra): Ditrupa limestones, soft limestones with Ostrea and homogeneous limestones with Milliolids (Fig. 8A, left-hand diagram). For the architectural elements, the three major facies correspond only to $73 \%$ of the elements. Limestones are more varied with non-capillary and hard stones being used in addition to soft and porous ones (Fig. 8B, right-hand diagram). The preferential selection of particular facies for monumental architecture or for the funerary steles is definitely visible. In Gallo-Roman monuments, the use of the different Lutetian limestones seems to be very specific. For example, some are used only for flagstones and steps, while others are mainly employed for pediments and cornices, i.e. the upper parts of the monument. It is then possible to define, as shown in Fig. 9, facies after facies, the use made of these various stones by the Gallo-Roman builders and to note that some stones show mixed monumental and funeral uses, whereas others are exclusively used in monuments. These stones are then preferentially found in a specific architectural position, such as Cerithium limestones from the upper Lutetian, which are found only at the bases.

In the special case of the Rheims Cathedral, many different stones, mostly from the Lutetian, were used for restoration purposes (SaintMaximin or Savonnières). Sometimes, limestones from the three groups described in Table 2 can be found in the same wall. This heterogeneity of material implies caution in the use of conservation treatments since the stone's behaviour may be very different (Fronteau et al., 1999b; Nicholson, 2000; Cardell et al., 2003).

All these stones have different characteristics. Courville stone has a porosity of $20 \%$, with very fine pores (0.1$0.2 \mu \mathrm{m}$ ), while Savonnières and Saint-Maximin limestones can have a porosity up to $40 \%$, with bigger pores. Also the water capillary absorption is very diverse. While Courville and Savonnières stones have a low capillary coefficient $\left(w=1.5 \mathrm{kgm}^{-2} \mathrm{~h}^{-1 / 2}\right)$, Saint-Maximin limestone is very capillary: ten times more than the Courville stone $(w=16$ $\mathrm{kgm}^{-2} \mathrm{~h}^{-1 / 2}$ ). Thus, their ability to withstand degradation is unequal. Moreover, their weathering will differ not only according to their physical properties, but also to their porous network and sedimentological composition (Benavente et al., 2004).

\section{Response variability to treatment}

The preliminary results of two studies, planned to last 10 years, started in 1995 and 1998, initiated by the "Cercle des Partenaires du Patrimoine" and the "Laboratoire de Recherche des Monuments Historiques"-LRMH- (Leroux and Boutin,1999;Boutin and Leroux,2000), on the natural ageing of stone and water-repellent treatments tend to confirm the great response variability to treatments of the various facies of Lutetian limestones. Different types of limestones, used in monuments of the Champagne-Ardenne region, were treated with a polysiloxane in organic solvent (Rhodorsil H224, from Rhodia), by brush, till the saturation of the stone surface. Then, four sets of stone samples were exposed to the natural environment on the top of a tower of Rheims cathedral, to face the same weathering as the cathedral's stones. The four sets of stone samples were removed from the sites after different times of exposure: 1, 3, 5 and 9 years. Capillary water uptake measurements, according to the Rilem 
FRONTEAU G., Moreau, C., Thomachot-Schneider, C., and Barbin, V., 2010, Variability of some Lutetian building stones from the Paris Basin, from characterisation to conservation: Engineering Geology, vol. 115. p. 158-166.

doi:10.1016/j.enggeo.2009.08.001

Recommendation (Test No.II.6) were performed on the different sets of samples to evaluate the durability of the water-repellent treatment.

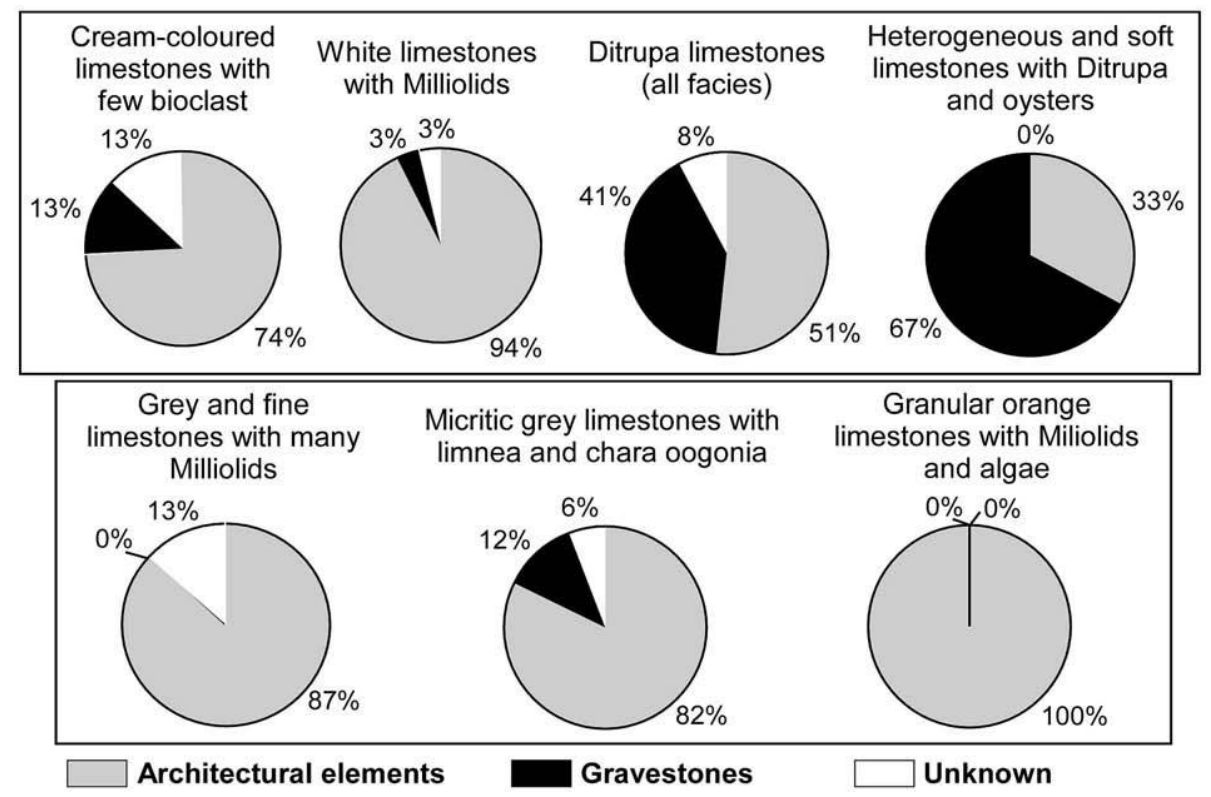

Fig. 9. Ancient preferential uses of the different Lutetian limestones deduced from the petrographical analysis of Gallo-Roman block from the archaeological site of Belin (Rheims).
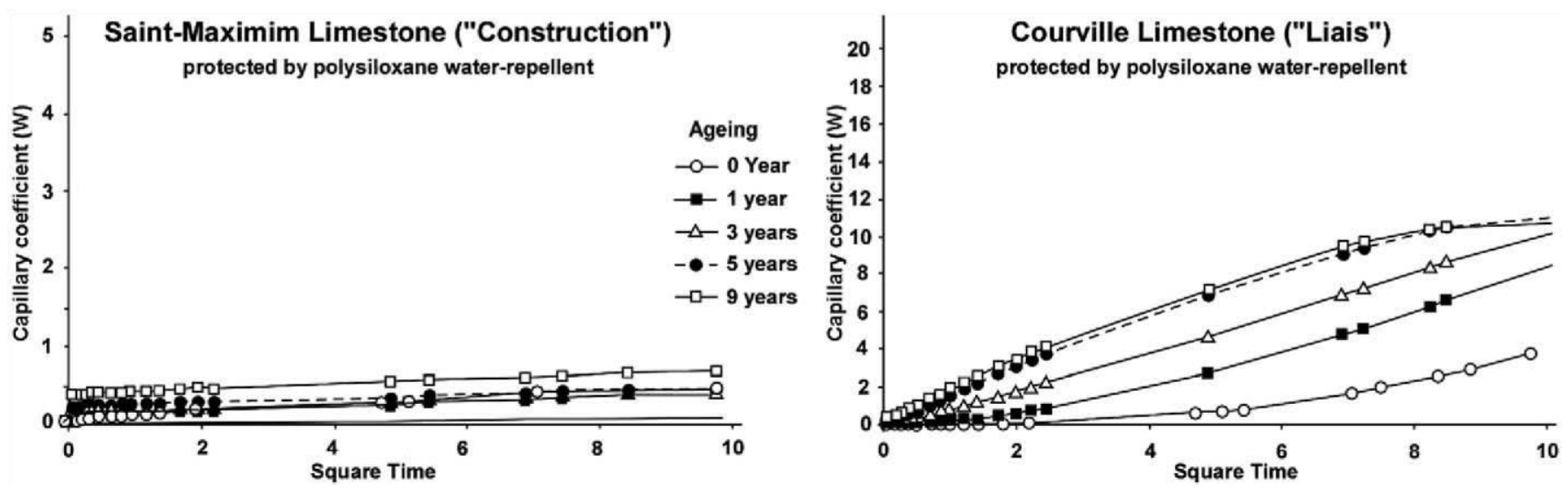

Fig. 10. Capillary water uptake measurements on two limestones protected by a polysiloxane water-repellent. Results after 1 to 9 years of exposure on the top of the Rheims

Cathedral.

Fig.10 displays the results of the measurements on Courville and Saint-Maximin stones, respectively from "Liais" bed and "Construction" bed, with different times of exposure. While the treatment remains efficient for SaintMaximin even after 9 years of exposure ( $w<0.1 \mathrm{kgm}^{-2} \mathrm{~h}^{-1 / 2}$ even after 9 years), it is clearly visible that the waterrepellent steadily loses its efficiency on the Courville stone. After 9 years of exposure the water capillary coefficient rises from $0.1 \mathrm{kgm}^{-2} \mathrm{~h}^{-1 / 2}$ to $1.4 \mathrm{kgm}^{-2} \mathrm{~h}^{-1 / 2}$, which almost corresponds to the water capillary coefficient of untreated Courville stone. The water-repellent might have formed a film on the surface, without penetrating in the Courville stone porosity, probably due to the low capillary absorption and the very fine pores. After short-term natural exposure the weathered film seems not to remain efficient. On the Saint-Maximin stone, the higher capillary 
FRONTEAU G., Moreau, C., Thomachot-Schneider, C., and Barbin, V., 2010, Variability of some Lutetian building stones from the Paris Basin, from characterisation to conservation. Engineering Geology, vol. 115. p. 158-166. doi:10.1016/j.enggeo.2009.08.001

properties allow a better penetration of the treatment and a good durability of the water-repellent efficiency. According to these preliminary results, it seems very difficult to obtain efficient water-repellent treatments on the Courville stone, whereas protected Saint-Maximin stone shows a good behaviour.

\section{Conclusions}

The geological and sedimentological study of outcrops and quarries and the material analyses on monuments showed large sedimento-diagenetic facies variability in the Lutetian limestones, together with differences in physical properties.

The variability of these stones is very important and may be linked to Lutetian paleogeography with variations of the sedimentary or diagenetic contexts. In the study area, these parameters influence stone resource availability and the maximum thickness of banks. Consequently, they control the profitability and the safety of the exploitations. This can explainwhyLutetianlimestonesarestillquarriedintheOiseortheareaof Soissonnais until our days, while quarries completely disappeared in the eastern part of the deposits.

Our work on the variability of Lutetian limestones in its eastern edge showed a large stone range closely related to its particular sedimentary context. Some lateral shift of facies may be mapped using outcrops recognition coupled to old quarries and building or monument studies. Precise mapping of these facies evolutions aiming at defining the location of each stone family will be one of our objectives for future studies.

The other aspect of our future work will concern the measurement of petrophysical properties for the various limestones recognized in this preliminary study, in order to check whether the supposed old empirical or practical knowledge of the durability of these stones (preferential stone use during Gallo-Roman or Medieval times) can be retraced and quantified by modern techniques of material characterisation. In addition, tests on other naturally weathered stones, untreated or protected by various treatments will be carried out. This will help to quantify the behaviour of the different building stones from or used in the study area, finding acceptable couple limestone/water-repellent in various environmental conditions.

\section{References}

Andriani, G.F., Walsh, N., 2003. Fabric, porosity and water permeability of calcarenites from Apulia (SE Italy) used as building and ornamental stone. Bulletin of Engineering Geology and the Environment 62, 77-84.

Beck, K., Al-Muktar, M., Rozenbraum, O., Rautureau, M., 2003. Characterization, water transfer properties and deterioration in tuffeau: building material in the Loire valley - France. Building and Environment 38, 1151-1162.

Bedon, R. 1984. Les carrières et carriers de la Gaule Romaine. Les carrières dans I'histoire. Ed. Picard.

Benavente, D., Garcia del Cura, M.A., Fort, R., Ordonez, S., 2004. Durability estimation of porous bulding stones from pore structure and strength. Engineering Geology 74, 113-127.

Benoit, P., Blanc, A., Gély, J.-P., Guini-Skliar, A., Obert, D., Viré, M. 2000. La pierre de Paris, méthode d'extraction de la pierre à bâtir depuis son extraction jusqu'à sa mise en œuvre. Mém. 3 du musée d'Argentomagus. 18ème Suppl. Revue archéo. Centre de la France. Actes du Colloque d'Argentomagus: La pierre dans la ville antique et médiévale. 30-31 Mars 1998. Ed Lorenz J., Tardy D. et Coulon G. pp. 121-158.

Blanc, A., 1998. La pierre et les carrières à Laon et dans le Laonnois. Bulletin d'information AGBP 35, 9-15.

Blanc, A., Holmes, L., Harbottle, G., 2002. Lutetian limestone in the Paris region: petrographic and compositional characterization. London. In: Herrmann, J.J., Herz Jr., Norman, Newman, R. (Eds.), Proceedings of the fifth international conference of ASMOSIA, Museum of fine arts, Boston, 11-15 June 1998, pp. 103-109. 
FRONTEAU G., Moreau, C., Thomachot-Schneider, C., and Barbin, V., 2010, Variability of some Lutetian building stones from the Paris Basin, from characterisation to conservation. Engineering Geology, vol. 115. p. 158-166. doi:10.1016/j.enggeo.2009.08.001

Blondeau, A. 1965. Le Lutétien des bassins de Paris, de Belgique et du Hampshire, étude sédimentologique et paléontologique. Thesis. Paris. 465 p.

Blondeau, A., 1970. Le calcaire grossier du Bassin de Paris. Bulletin of the B.R.G.M. II 4, 7-17.

Blows, J.F., Carey, P.J., Poole, A.B., 2003. Preliminary investigations into Caen Stone in the UK; its use weathering and comparison with repair stone. Building and Environment 38, 1143-1149.

Boutin, F., Leroux, L., 2000. Color and weight evolution of limestones protected by water repellents after three-year ageing period in urban conditions. 9th International congress on deterioration and conservation of stone: proceedings, Venice, June19-24, 2000, vol.2, pp. 197-205.

Cardell, C., Delalieux, F., Roumpopoulos, K., Moropoulou, A., Auger, F., Van Grieken, R., 2003. Salt-induced decay in calcareous stone monuments and buildings in a marine environment in SW France. Construction and Building Materials 17, 165-179.

Devos, A., Sosson, C., Lejeune, O., Fronteau, G. 2005. Rôle des contextes géomorphologique et géologique dans l'abandon des carrières de pierre du Lutétien autour de Reims. International symposium 'Pierres du patrimoine européen: Economie de la pierre de I'Antiquité à la fin du XVIIle siècle en Europe'; Château-Thierry. 18-21 Octobre 2005. p. 64

Dolfini, L., 1920. Recherches de Carrières. Rapport Ministère de I'Instruction Publique et des Beaux Arts, Reims. 20 pp.

Dreesen, R., Dusar, M., 2004. Historical building stones in the province of Limburg (NE Belgium): role of petrography in provenance and durability assessment. Materials Characterization 53, 273-287.

Dunham, R.J., 1962. Classification of carbonate rocks according to depositional texture. American Association of Petroleum Geologists Memoir 1, 108-121.

ECS (1999) EN 1925: Natural stone test methods - Determination of water absorption coefficient by capillarity. European Commitee for Standardization. EuropeanStandard. Brussels.

ECS (2005) EN 14579: Natural stone test methods - Determination of sound speed propagation. European Commitee for Standardization. European Standard. Brussels.

ECS (2007) EN 1936: Natural stone test method - Determination of real density and apparent density, and of total and open porosity. European Commitee for Standardization. European Standard. Brussels.

Folk, R.L., 1959. Practical petrographical classification of limestones. American Association of Petroleum Geologists Memoir 43.1, 1-38.

Folk, R.L., 1962. Spectral subdivision of limestone types. American Association of Petroleum Geologists Memoir 1, 62-84.

Fronteau, G. 2000. Comportements télogénétiques des principaux calcaires de Champagne-Ardenne en relation avec leur faciès de dépôt et leur séquençage diagénétique. PhD Thesis of Rheims University. 320 p. unpublished.

Fronteau, G., Barbin, V., Pascal, A., 1999a. Microfacies characterization of heterogeneous limestones by image analysis, relation with quarry sites: some building stones from the Paris basin. Geovision 99, 97-100 Liège (Belgique).

Fronteau, G., Barbin, V., Pascal, A., 1999b. Impact du faciès sédimento-diagénétique sur l'altération en oeuvre d'un géomatériau. Comptes Rendus de l'AcadeÂmie des Sciences Paris 328, 671-677.

Gély, J.-P., 1996. Le Lutétien du Bassin de Paris: de l'analyse séquentielle haute résolution à la reconstitution paléogéographique. Bulletin d'Information des Geologues du Bassin de Paris 34, 2-37.

Gély, J.-P., Blanc, A., Guini-Skliar, A., Lorenz, J., Viré, M. 2000. Les souterrains de Paris. Les anciennes carrières souterraines. Ed. Nord Patrimoine. 192 p.

Kaufmann, O., Quinif, Y., 1999. Cover-collapse sinkholes in the "Tournaisis" area, southern Belgium. Engineering Geology $52,15-22$. 
FRONTEAU G., Moreau, C., Thomachot-Schneider, C., and Barbin, V., 2010, Variability of some Lutetian building stones from the Paris Basin, from characterisation to conservation. Engineering Geology, vol. 115. p. 158-166. doi:10.1016/j.enggeo.2009.08.001

Leroux, L., Boutin, F. 1999. Urban atmospheric pollution and natural ageing of stones protected by water repellents. 8th international symposium: transport and air pollution including COST 319 final conference, Graz, Austria, 31, May 2, June 1999. Section IX/15.

Martinez-Torrez, L.M., 2007. Lithological maps of churches in the Diocese of Vitoria (Spain): space-time distribution of building stones and ancient quarries. Building and Environment 42, 860-865.

Molina, E., Cosovic, V., Gonzalvo, C., Von Salis, K., 2000. Integrated biostratigraphy across the Ypresian/Lutetian boundary at Agost, Spain. Revue de Micropaleontologie 43, 381-391.

Nicholson, D.T., 2000. Pore properties as indicators of breakdown mechanisms in experimentally weathered limestones. Earth Surface Processes and Landforms 26, 819-838.

Noël, P. 1970. Pierres de taille de France. Société de diffusion des Bâtiments et Travaux Publics. 261 p.

Roels, S., Carmeliet, J., Hens, H., 2000. Microscopic analysis of imbibition processes in oolitic limestone. Geophysical Research Letters 27, 3533-3536.

Schubnel, H.J., Frölich, F., Blanc, A., Blondeau, A., Cornée, A., de Wewer, P., Fabre, J.C., Gély, J.P., Malfay, J.P., Viré, M., 2000. In: Frölich, F., Schubnel, H.J. (Eds.), Le Lutétien, la Pierre de Paris. Muséum national d'histoire naturelle, Paris, p. 53 pp.

Topal, T., Sözmen, B., 2003. Deterioration mechanisms of tuffs in Midas monument. Engineering Geology 68, $201-223$.

Viré, M. 1997. Le nom des bancs exploités dans le calcaire grossier à Paris: étymologie et géologie. In "Pierres \& carrières: Géologie - Archéologie - Histoire: textes réunis en hommage à Claude Lorenz," Paris, Centre de recherches historiques et juridiques de I'Université Paris I, 17-18 november 1995. pp. 183-186.

Zezza, U., 1990. Physical-mechanical properties of quarry and building stones. In: Veniale, F., Zezza, U. (Eds.), Analytical Methodologies of Damage Stones, pp. 1-20. Pavia. 